\title{
KAJIAN AWAL FITOREMEDIASI MERKURI PADA Caulerpa serrulata DAN Halimeda macroloba DARI PERAIRAN TELUK TOTOK
}

\author{
(Initial Study of Mercury Phytoremediation in Caulerpa serrulata and \\ Halimeda macroloba from Totok Bay)
}

\author{
Dedy Octavian Siahaan ${ }^{1 *}$, Desy M. H. Mantiri ${ }^{1}$, Antonius Rumengan ${ }^{1}$
}

1. Program Studi IImu Kelautan, Fakultas Perikanan dan IImu Kelautan, Universitas Sam

Ratulangi, Manado

*e-mail : dedy.siahaan@gmail.com

The study was conducted with the aims to test Caulerpa serrulata and Halimeda macroloba as agents of mercury phytoremediation in seawater. Analysis of mercury in sediment and algae tissues based on the standard methods United State Environmental Protection Agency (USEPA) in Water Laboratory Nusantara (WLN) and inspection method using Inductively Coupled Plasma Mass Spectroscopy (ICP-MS) instrument. The results showed that, Caulerpa serrulata is able to absorb 0.20 ppm mercury and Halimeda macroloba absorb 0.11 ppm from Totok Bay. Besides that, the ability of Caulerpa serrulata and Halimeda macroloba to tolerated high levels of mercury in sediment where algae grow, could be considered that Caulerpa serrulata and Halimeda macroloba has potential as an agent phytoremediator mercury in seawater.

Keywords: Phytoremediation, Mercury, Caulerpa serrulata, Halimeda macroloba

Penelitian ini dilakukan dengan tujuan untuk mengetahui kemampuan alga spesies Caulerpa serrulata dan Halimeda macroloba sebagai agen fitoremediator merkuri di perairan laut. Analisis merkuri pada sedimen dan jaringan alga berdasarkan metode standar United State Environmental Protection Agency (USEPA) yang dilakukan di Water Laboratory Nusantara (WLN) dengan menggunakan Inductively Coupled Plasma Mass Spectroscopy (ICPMS) instrument. Hasil penelitian memperlihatkan bahwa Caulerpa serrulata mampu mengabsorbsi merkuri sebanyak $0,20 \mathrm{ppm}$ dan Halimeda macroloba mampu mengabsorbsi sebanyak 0,11 ppm dari perairan Teluk Totok. Selain itu kemampuan Caulerpa serrulata dan Halimeda macroloba mentoleransi kadar merkuri yang tinggi di sedimen tempat alga tersebut tumbuh bisa menjadi pertimbangan bahwa alga tersebut memiliki potensi untuk dapat digunakan sebagai salah satu organisme fitoremediaotor merkuri di perairan laut.

Kata kunci: Fitoremediasi, Merkuri, Caulerpa serrulata, Halimeda macroloba

\section{PENDAHULUAN}

Laut merupakan akhir dari berbagai jenis limbah, baik limbah pabrik, aktivitas pertambangan, limbah rumah tangga, residu pupuk maupun pestisida. Kondisi ini semakin buruk dengan kurangnya kesadaran sebagian masyarakat maupun pelaku industri bahwa limbah yang dibuang tanpa pengolahan yang sesuai standar memiliki dampak yang negatif terhadap ekosistem di laut maupun bagi manusia itu sendiri.

Di beberapa kota besar seperti Jakarta contohnya, setiap harinya hampir $7000 \mathrm{~m}^{3}$ limbah cair termasuk di antaranya yang mengandung logam berat yang dibuang melalui beberapa sungai yang akhirnya bermuara ke Teluk Jakarta (Lestari dan Edward' 2004). Pencemaran logam berat lainnya terjadi di perairan Dadap, Cilincing, Demak dan Pasuruan, berdasarkan hasil monitoring pada tahun 2001 dan 2002 menunjukkan bahwa kandungan $\mathrm{Hg}$ di perairan tersebut telah melebihi ambang batas yaitu diatas 2 ppm (Siregar dan Murtini dalam Komari et al., 2013). Di kota Manado sendiri beberapa sungai yang 
mengalir di sepanjang kota Manado seperti sungai Maasing dan sungai Tondano berada dalam status kualitas perairan dalam kategori tidak layak (Tarigan, 2013).

Menyadari ancaman yang begitu besar dari pencemaran logam berat, maka berbagai metode alternatif telah banyak digunakan seperti mengurangi konsentrasi logam berat yang akan dibuang ke perairan, tetapi dalam jangka waktu yang lama, perlakuan tersebut dapat merusak lingkungan akibat dari akumulasi logam berat yang tidak sebanding dengan masa perbaikan (recovery) dari lingkungan itu sendiri. Teknik yang lain seperti reverse osmosis, elektrodialisis, ultrafiltrasi dan resin penukar ion juga belum memberikan solusi yang efektif bagi masalah pencemaran lingkungan, selain biaya yang sangat tinggi, teknik tersebut justru menghasilkan limbah lainnya.

Saat ini telah dikembangkan salah satu metode yang dikenal dengan fitoremediasi untuk mengatasi pencemaran yang terjadi di perairan laut maupun daratan. Fitoremediasi adalah upaya penggunaan tanaman dan bagian-bagiannya untuk dekontaminasi limbah dan masalahmasalah pencemaran lingkungan. Seperti yang diungkapkan oleh Musfa (2012), fitoremediasi merupakan kemampuan tanaman tertentu untuk memperbaiki, menyembuhkan atau membersihkan kontaminan (pencemar /polutan) menjadi kurang atau tidak berbahaya bahkan menjadi bahan yang berguna secara ekonomi.

Berdasarkan kondisi tersebut, maka penelitian ini dilakukan dengan tujuan untuk mengetahui kemampuan fitoremediasi merkuri yang dilakukan oleh alga makro spesies Caulerpa serrulata dan Halimeda macroloba di perairan yang mengandung logam merkuri dengan kadar yang tinggi.

\section{METODE PENELITIAN}

Pengambilan sampel dilakukan di perairan Teluk Totok. Perairan tersebut dipilih karena perairan Teluk Totok diketahui merupakan daerah dengan kandungan logam emas, arsen dan mineral yang tinggi secara alamiah. (BTKL-PPM, 2005). Selain itu berdasarkan observasi lapangan, di Ratatotok banyak ditemukan tambang rakyat dengan ratusan trombol, sehingga aktivitas tambang di daerah tersebut diduga turut menyumbang tingginya kadar merkuri di perairan Teluk Totok. Oleh karena itu perairan Teluk Totok merupakan daerah yang tepat untuk menguji kemampuan fitoremediasi merkuri yang dilakukan oleh alga $C$. serrulata dan $H$. macroloba yang banyak ditemukan di perairan Teluk Totok.

Pengujian analisis merkuri pada sedimen dan alga berdasarkan metode standar United State Environmental Protection Agency (USEPA) yang dilakukan di Water laboratory Nusantara (WLN) dengan menggunakan metode Inductively Coupled Plasma Mass Spectroscopy (ICP-MS) instrument. Secara garis besar pengujian kandungan merkuri dilakukan dalam dua bagian yaitu :

\section{Penetapan Kadar Air}

Penetapan kadar air dilakukan dengan cara memanaskan sedimen dalam oven dengan suhu $105^{\circ} \mathrm{C} \pm 5^{\circ} \mathrm{C}$ selama 24 jam, kemudian didinginkan dalam desikator, lalu ditimbang.

\section{Digest}

Ditambahkan $5 \mathrm{ml} \mathrm{HNO}_{3}$ pekat, kemudian diikuti dengan penambahan $5 \mathrm{ml} \mathrm{HCL}$ pekat ke dalam 5 gram sampel sedimen. Lalu dibiarkan selama satu jam lalu dipanaskan pada suhu $85^{\circ} \mathrm{C}-90^{\circ} \mathrm{C}$ selama 2 jam. Kemudian didinginkan. Selanjutnya sampel ditambahkan $50 \mathrm{ml}$ air ultrapure dan 
terakhir di centrifuge dengan kecepatan 2000-3000 rpm selama 10 menit.

Secara garis besar proses digest pada sampel alga juga sama dengan sampel sedimen, proses dimulai dengan menambahkan $5 \mathrm{ml}$ $\mathrm{HNO}_{3}$ pekat pada wadah piala gelas yang telah berisi 5 gram sampel alga, lalu dibiarkan selama 6 jam agar terjadi penghancuran dingin. Setelah itu sampel dipanaskan pada suhu $85^{\circ} \mathrm{C}$ selama 1 jam lalu didinginkan kembali hingga suhu ruang. Setelah itu tambahkan $2 \mathrm{ml} \mathrm{H}_{2} \mathrm{O}_{2} \quad 30 \%$ pada sampel yang sudah didinginkan kemudian dipanaskan pada suhu $85^{\circ} \mathrm{C}$ selama 1 jam kemudian didinginkan. Proses terakhir adalah sampel disaring dengan menggunakan kertas saring kualitatif dan diencerkan dengan $50 \mathrm{ml}$ air ultrapure. Sampel siap dianalisis dengan menggunakan Inductively Coupled Plasma Mass Spectroscopy (ICP-MS) instrument.

\section{HASIL DAN PEMBAHASAN}

\section{Kandungan Merkuri pada Sedimen dan Jaringan Alga}

Lokasi pengambilan sampel di perairan Teluk Totok memiliki substrat pasir berbatu dengan sedikit lumpur. Air laut di Teluk Totok cenderung berwarna coklat. Kondisi perairan yang keruh disebabkan oleh keberadaan sungai besar yang bermuara ke perairan Teluk Totok yang membawa banyak sedimen dari daratan masuk ke laut.

Berdasarkan hasil pengujian laboratorium diketahui bahwa kandungan merkuri pada sedimen dari perairan Teluk Totok telah melewati batas baku mutu seperti yang ditetapkan oleh ASEAN-Marine Water Quality (1999) yaitu 0,4 ppm - 350 ppm untuk kategori tercemar (polluted). Tingginya kandungan merkuri pada
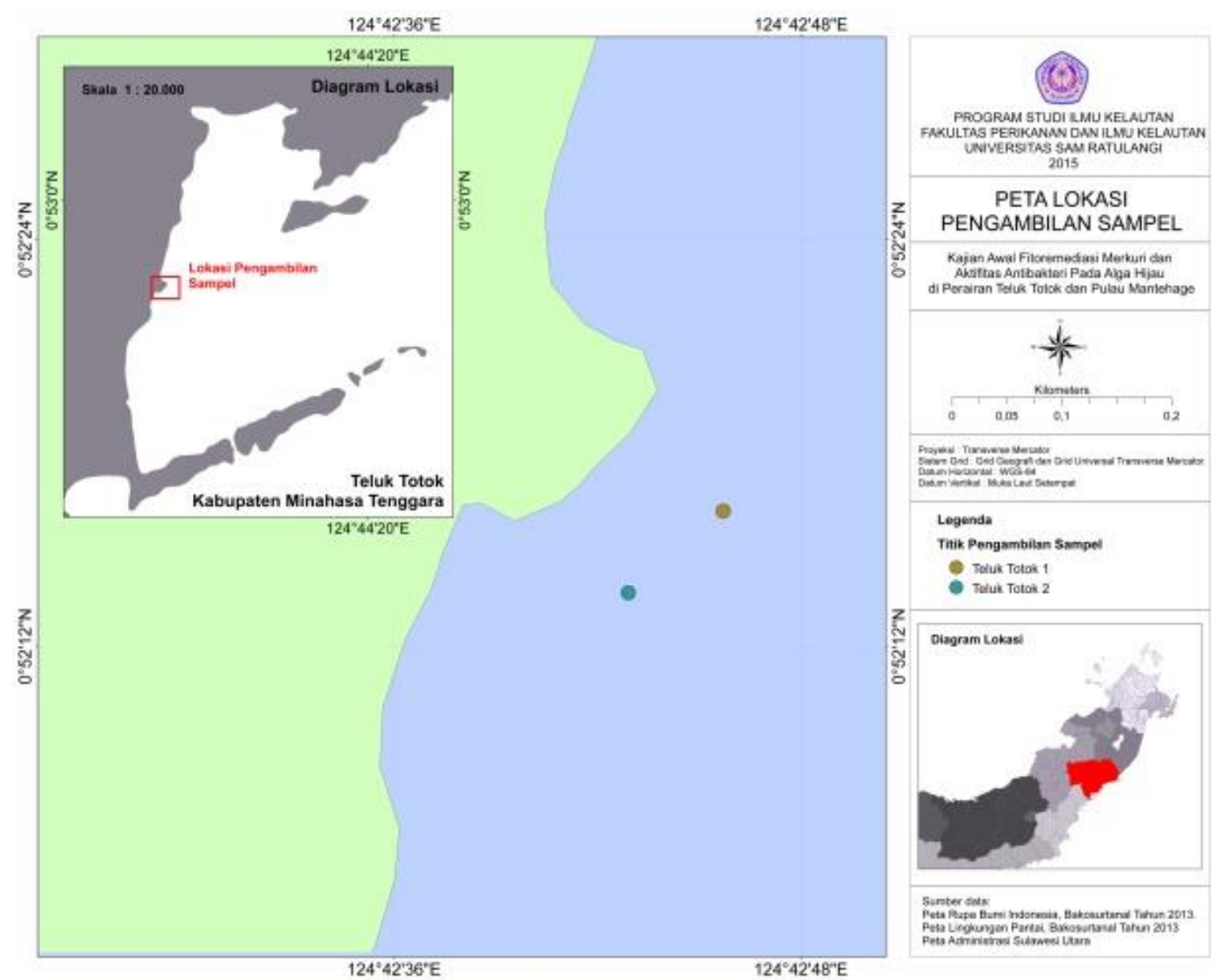

Gambar 1. Lokasi pengambilan sampel (diadaptasi dari Google Earth, 2015). 
sedimen di perairan Teluk Totok, dikarenakan wilayah tersebut merupakan daerah termineralisasi (mineralized area) sehingga secara alami daerah tersebut mengandung logam merkuri dengan kadar yang tinggi secara alami.

Penelitian yang dilakukan oleh BTKL-PPM (2005) pada air sumur galian di beberapa desa di Ratatotok dan Buyat menemukan hasil bahwa kandungan arsenik yang lebih tinggi pada air sumur galian pada saat musim hujan dengan kisaran terendah 0,04 $\mathrm{mg} / \mathrm{l}$ dan tertinggi $0,1 \mathrm{mg} / \mathrm{l}$, dibandingkan pada saat musim kemarau dengan kisaran terendah $0,003 \mathrm{mg} / \mathrm{l}$ dan tertinggi $0,051 \mathrm{mg} / \mathrm{l}$. Hal ini disebabkan aliran air permukaan sebagai media transportasi logam arsen. Oleh karena itu kemungkinan proses yang sama juga bisa terjadi pada logam merkuri. Air hujan yang berasal dari daratan mengikis lapisanlapisan sedimen yang akhirnya masuk ke sungai dan bermuara di perairan Teluk Totok. Selain itu kegiatan pertambangan skala kecil yang berada di wilayah tersebut juga mempengaruhi tingginya kadar merkuri di perairan Teluk Totok. Seperti yang diungkapkan oleh Purnawan et al. (2013), kegiatan anthropogenik yang menghasilkan limbah merkuri dapat menyumbang tingginya kadar merkuri di suatu perairan.

\section{Potensi Kemampuan Fitoremediasi C.serrulata dan H.macroloba}

Kemampuan C.serrulata dan
H.macroloba sebagai agen
fitoremediator merkuri yang ada di
perairan ternyata memiliki potensi untuk
dimanfaatkan. Berdasarkan hasil
analisis kandungan logam merkuri yang
ada di dalam jaringan kedua alga
tersebut C.serrulata mampu menyerap
0,20 ppm merkuri dari kedua titik
pengambilan sampel di perairan Teluk
Totok, sedangkan H.macroloba mampu
menyerap 0,11 ppm logam merkuri dari

sedimen yang berasal dari kedua titik pengambilan sampel.

Walaupun kemampuan kedua jenis alga tersebut dalam menyerap logam merkuri tidak signifikan, namun kandungan merkuri dalam jaringan alga tersebut telah melewati batas baku mutu yang ditetapkan oleh keputusan Menteri Lingkungan Hidup Nomor 51 tahun 2004 yaitu, 0,001 ppm. Oleh sebab itu perlu dilakukan penelitian lanjut untuk mengetahui batas maksimum kemampuan kedua jenis alga tersebut dalam menyerap merkuri.

Keberadaan logam merkuri yang bukan salah satu unsur yang mendukung pertumbuhan dalam jaringan alga, akan memiliki sifat toksik bagi alga tersebut. Seperti yang diungkapkan oleh Hall (2002), bahwa keberadaan logam berat pada tubuh tumbuhan akan menggangu proses pertumbuhan, metabolisme dalam tubuh dan gangguan reproduksi.

Namun ada hal yang menarik, walaupun sedimen di perairan Teluk Totok mengandung merkuri dengan kadar yang cukup tinggi, tetapi populasi C.serrulata dan H.macroloba cukup banyak di perairan tersebut, hal ini mengindikasikan bahwa kedua jenis alga tersebut mampu bertahan dengan kondisi faktor abiotik habitat yang cukup ekstrim. Selain itu berdasarkan pengamatan, secara morfologi kedua jenis alga tersebut tampak dengan blade, stipe dan holdfast yang normal, walaupun apabila kedua jenis alga tersebut dibandingkan dengan C.serrulata dan H.macroloba yang diambil dari Pulau Mantehage terlihat ukuran pertumbuhan alga yang diambil dari Teluk Totok tidak tumbuh dengan maksimal.

Penelitian yang pernah dilakukan oleh Wowor (2000) terhadap mikro alga Dunaliella sp. menunjukkan bahwa mikro alga tersebut masih dapat hidup dengan kondisi ekstrim dalam media kultur yang telah di tambahkan logam cadmium (Cd) dan tembaga $(\mathrm{Cu})$ dengan berbagai variasi konsentrasi 


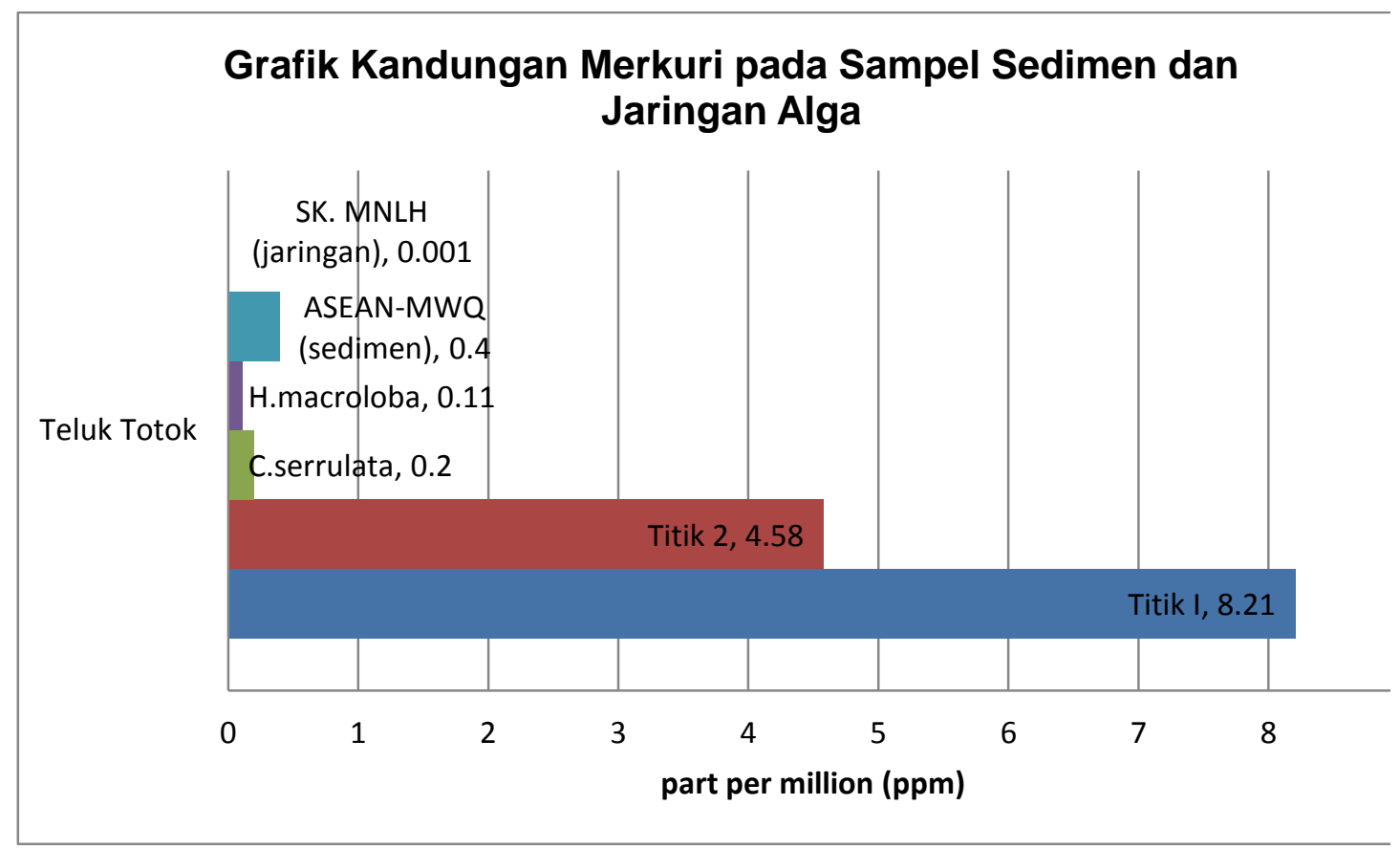

Gambar 2. Grafik kandungan merkuri pada sampel sedimen dan jaringan alga.

mulai dari $0,03 \mathrm{ppb}$ sampai 3,0 ppb, walaupun dalam penelitian lanjut diketahui semakin tinggi kandungan logam dalam media kultur, maka konsentrasi pigmen dalam mikro alga tersebut menurun.

Walaupun perlu dilakukan penelitian lanjut untuk mengetahui berapa banyak kadar logam merkuri yang mampu ditoleransi oleh kedua jenis alga tersebut dalam jaringan tubuhnya namun melalui penelitian ini telah didapatkan informasi bahwa kedua jenis alga tersebut diduga

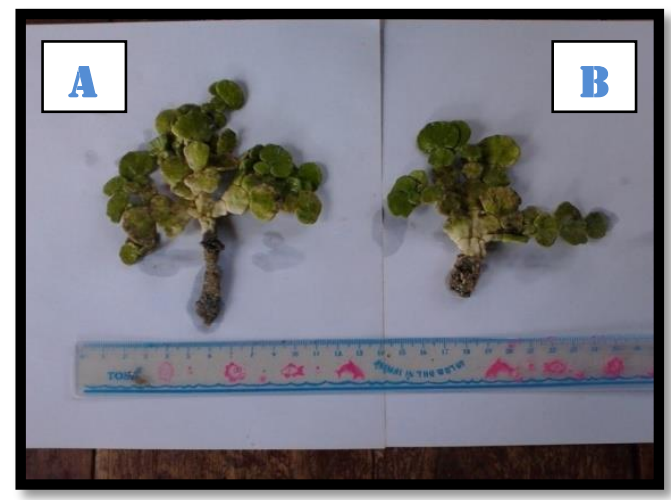

Gambar 4. Alga Halimeda macroloba A.Pulau Mantehage

B.Teluk Totok mampu dijadikan sebagai agen fitoremediator logam merkuri di pesisir Oleh sebab itu sebelum menentukan apakah suatu tumbuhan dapat dikategorikan sebagai tumbuhan fitoremediator, terdapat beberapa kriteria sebelum menentukan kedua

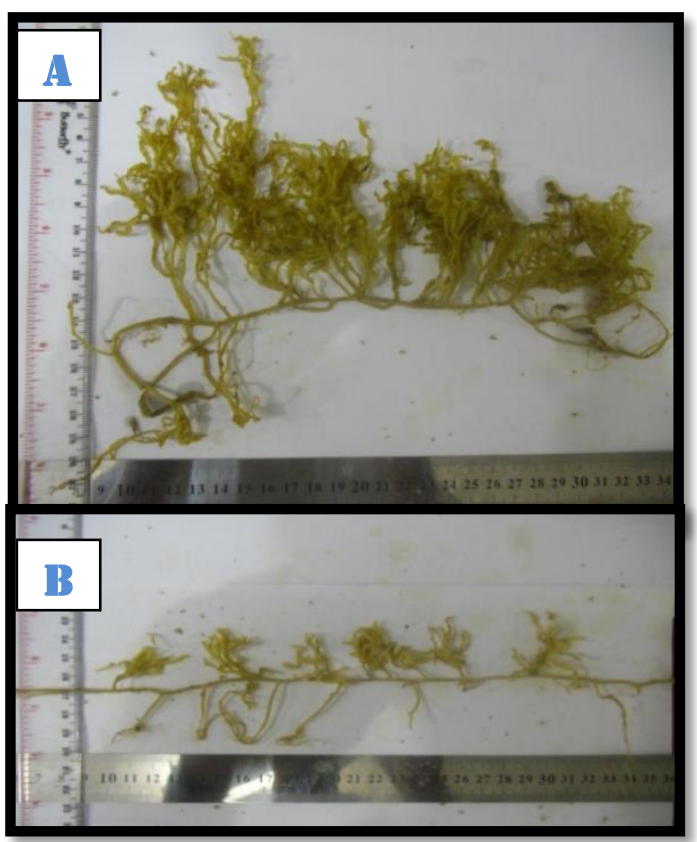

Gambar 3. Alga Caulerpa serrulata
A.Pulau Mantehage
B.Teluk Totok 
jenis alga tersebut sebagai agen fitoremediator seperti yang diungkapkan oleh Mujare and Bulow (2001) yaitu, mampu menyerap logam berat dengan kadar yang tinggi setidak 1-3 \% berat kering, memiliki biomassa yang tinggi dan pertumbuhan yang cepat. Maka dari itu perlu dilakukan penelitian lanjut untuk mengetahui kemampuan maksimum dan siklus hidup kedua jenis alga tersebut, agar dapat menjadi referensi salah satu tanaman laut yang berperan sebagai agen fitoremediator logam merkuri.

\section{KESIMPULAN}

C.serrulata dan H.macroloba mampu mengabsorbsi logam merkuri di perairan Teluk Totok, selain itu keberadaan populasi kedua jenis alga tersebut di perairan dengan kadar merkuri yang tinggi pada sedimen menjadi bukti bahwa C.serrulata dan H.macroloba mampu mentoleransi logam merkuri pada jaringan tubuhnya. Oleh sebab itu C.serrulata dan H.macroloba memiliki potensi untuk dapat dikembangkan sebagai salah satu agen fitoremediator merkuri di perairan laut di masa yang akan datang.

\section{DAFTAR PUSTAKA}

BTKL-PPM. 2005. Analisis Kandungan Total Arsen pada Sumur Gali di Desa Buyat Kecamatan Kotabunan Kabupaten Bolaang mangondow Tahun 2005. Departemen Kesehatan R.I Direktorat Jenderal PPM-PL. Manado

Hall, J. L. 2002. Cellular Mechanism for Heavy Metal Detoxification and Tolerance. Journal of Experimental Botany, Vol. 53, No. $366: 1-11$.
Komari, N., Irawati, U., Novita, E. 2013. Kandungan Kadmium dan Seng Pada Ikan Baung (Hemibagrus nemurus) di Perairan Trisakti Banjarmasin Kalimantan Selatan, Sains dan Terapan Kimia, Vol. 7, No. $1: 42-49$

Lestari. Edward. 2004. Dampak Pencemaran Logam Berat Terhadap Kualitas Air Laut dan Sumberdaya Perikanan (Studi Kasus Kematian Massal Ikan di Teluk Jakarta), Makara Sains, Vol. 8, No. $2: 52-58$

McPherson, C.A., Chapman, P.M., Vigers, G. A. \& Ong, K. S. 1999. ASEAN Marine Water Quality Criteria: Contextual Framework, Principles, Methodology and Criteria for 18 Parameters. ASEAN Marine Environmental Quality Criteria - Working Group (AMEQC-WG), ASEANCanada Cooperative Programme on Marine Science - Phase II (CPMS-II). EVS Environment Consultant, North Vancouver and Departement of Fisheries, Malaysia. 568 pp

Mejáre, M., Bülow, L. 2001. Metalbinding proteins and petides in bioremediation and phytoremediatin of heavy metals . Trends in Biotechnology, Vol. 19, No. 2 :67-73

Musfa, R. 2012. Fitoremediasi Upaya Mengolah Air Limbah Dengan Media Tanaman. Website : http://ratymusfa.blogspot.com/p/ fitoremediasi-upaya-air-limbahdengan.html (Diakases tanggal 27 November 2013)

Purnawan, Sandi. R. Sikanna. Prismawiryanti. 2013. Distribusi Logam Merkuri Pada Sedimen Laut Di Sekitar Muara Sungai Poboya. Online Jurnal of Natural Scince. Vol 2:1, hal 1824 ISSN 2338-0950 
Tarigan, A. 2011. Kajian Kualitas Limbah Cair Domestik di Bebarapa Sungai yang Melintasi Kota Manado Dari Aspek Bahan Organik dan Anorganik. Pesisir dan Laut Tropis, Vol. I, No. 1 :55-62

Wowor, P. S. 2000. Efek Logam Kadmium dan Tembaga Terhadap Kandungan Pigmen Dunaliella $s p$. Skripsi. FPIK. UNSRAT. 